\title{
PERAN LITERASI MORAL MENINGKATKAN KARAKTER RELIGIUS ANAK USIA DINI
}

\author{
Shanti Sudjarwati ${ }^{1}$, Eny Fariyatul Fahyuni ${ }^{2}$ \\ sudjarwatishanti@gmail.com \\ Universitas Muhammadiyah Sidoarjo
}

\begin{abstract}
This study aims to determine the important role of moral literacy in institutions with the authority of Islam to have a local curriculum that is Aisyiyahan and Muhammadiyahan, as well as to develop a habit of practicing dhuha in an orderly and smooth manner in reading, and diligently practicing charity at an early age. This research is a qualitative research. The subjects in this study were kindergarten students Aisyiyah Bustanul Athfal 5 which consisted of 17. Data collected through interviews and observations. The research results were analyzed using descriptive data analysis techniques. Based on research and calculations obtained an increase from $34 \%$ to $66 \%$ in the criteria for character development already praying in an orderly and smooth manner, while on Friday alms from 34\% to $66 \%$ reflecting behavior or morals, character, religious character is also significant because according to the target nominal amount expected.
\end{abstract}

Keywords: Religious literation of Moral, religious characters, early age

\begin{abstract}
Abstrak
Penelitian ini bertujuan untuk mengetahui peran penting literasi moral dalam lembaga yang bernuasa Islam memiliki kurikulum lokal yaitu ke- Aisyiyahan dan Ke- Muhammadiyahan, serta mengembangkan pembiasaan sholat dhuha dengan tertib dan lancar dalam bacaannya, dan rajin bersedekah melatih rasa empati pada usia dini. Penelitian ini merupakan penelitian kualitatif. Subjek dalam penelitian ini ialah peserta didik TK Aisyiyah Bustanul Athfal 5 yang terdiri atas 17. Data dikumpulkan melalui wawancara dan observasi. Data hasil penelitian dianalsis menggunakan teknik analisis data deskriptif. Berdasarkan penelitian dan perhitungan diperoleh peningkatan dari angka $34 \%$ menjadi $66 \%$ pada kriteria pengembangaan karakter sudah sholat dengan tertib dan lancar, sedangkan pada jum'at sedekah dari $34 \%$ menjadi $66 \%$ yang mencerminkan perilaku atau akhlak, budi pekerti, karakter religius juga signifikan karena sesuai target jumlah nominal yang diharapkan.
\end{abstract}

Kata Kunci: Literasi Moral, Karakter Religius, Anak Usia Dini 


\section{PENDAHULUAN}

Menurut Thomas Licona ( 2015: 61) Pendidikan moral bisa dilakukan di sekolah dengan nilai-nilai yang telah diajarkan disekolah, mempunyai nilai yang bermanfaat dan terima masyarakat sekitar dengan beraneka ragam. Sekolah tidak hanya sebagai sarana dan fasilitas memberikan nilai-nilai kepada anak, tetapi anak dapat juga memahami dan melaksanakan nilai-nilai yang telah disampaikan oleh guru atau pendidik. Pendidikan moral berkembang dengan terwujudnya pembiasaan tingkah laku yang bisa dilihat dari perbuatan baik dan buruk, sikap religius yang tinggi sesuai Alquran dan hadist dan bertanggung jawab serta disiplin. Menurut Lawrence Kohlberg ( Monks dan Knoers, 2011). Kemampuan anak untuk mengenali perilaku dalam prinsip moral diperlukan perkembangan anak untuk bersosialisasi meningkatkan perkembangan kepribadian yang terasah dalam perkembangan bermasyarakat, berteman dan dalam lingkungan sekitarnya,lembaga pendidikan sangatlah menentukan tercapainya kualitas pendidikan dan pembelajaran kepada peserta didik, dalam penyampaian pembelajaran berupa bentuk literasi moral juga dibutuhkan tahapan yang tidak instan, karena literasi moral merupakan pembiasaan yang dilakukan secara kontinue kepada anak usia dini. Sehingga literasi berupa budi pekerti merupakan pedoman dasar sebagai benteng moral pada anak usia dini, dengan adanya pendidikan moral dilembaga maka literasi akan mengikuti dengan sendirinya sebagai wawasan dan dasar pengembangan literasi moral.

Literasi sendiri merupakan keterampilan dalam sebuah pemilihan materi, pendistribusian dan suatu kompetensi yang saling terkait, di tingkatan jenjang pendidikan,menurut nurdiyanti bahwa literasi adalah dasar pengetahuan anak untuk belajar dalam ketrampilan menulis maupun membaca (Nurdiyanti 2010). Kegiatan literasi tidak hanya membaca, tetapi juga dilengkapi kegiatan yang harus dilandasi dengan keterampilan atau kiat untuk mengubah meringkas, memodifikasi, menceritakan kembali materi yang telah diajarkan (Wachidah, Suwignyo, and Widiati 2017). Kegiatan literasi mencakup keahlian nonverbal, keterampilan dalam menyimak-berbicara, keahlian visual, berpikir kritis, hingga keahlian teknologi (Pancarrani, Amroh, and Noorfitriana, 2017). Literasi merupakan keterampilan yang disampaikan tidak hanya menulis dan membaca tetapi suatu cara atau metode untuk mengembangkan 
pembelajaran dengan kreatif dan inovatif dalam segala bidang, terutama pengembangan moral anak usia dini, anak perlu adanya tauladan dan contoh secara nyata agar bisa memahami dan menerapkan pengetahuan yang diperoleh dalam pembelajaran yang disampaikan guru sebagai sumber daya manusia pendukung serta fasilitator menurut Mahsun dalam Permendikbud : 2015 bahwa aktivitas tersebut merupakan kegiatan yang saling berhubungan untuk membentuk Sumber Daya Manusia (SDM) yang berkualitas tinggi melalui proses belajar aktif yang bermakna.

Gerakan literasi dalam sekolah saat ini merupakan upaya pemerintah menumbuhkan budi pekerti peserta didik sebagai acuan untuk memiliki budaya akhlak atau moral yang baik menurut kriteria agama terutama agama Islam, sehingga dapat tercipta pembelajaran akhlak sampai dewasa. Sehingga peran literasi di sini sebagai kegiatan yang bertujuan untuk menanamkan budi pekerti peserta didik. Sejalan dengan Cooper, J.D, Literacy: Helping Children Construct Meaning. 30. Bahwasanya literasi akan berkembang menjadi kebiasaan dengan proses yang lama dan bertahap sehingga upaya pemerintah melalui tahapan yang dinamis dan berkelanjutan dengan dipengaruhi oleh tiga komponen yaitu motivasi, pembelajaran terpadu dan mandiri menjadi suatu kompenen yang tertait dan saling mendukung untuk menjadikan anak mempunyai literasi (Boston Toronto: Hougton Miffin Company,1993).

Pendidikan karakter dapat didefinisikan sebagai segala usaha yang dapat dilakukan untuk mempengaruhi karakter siswa. Thomas Lickona menyatakan bahwa pengertian pendidikan karakter adalah usaha yang disengaja untuk membantu seseorang sehingga ia dapat memahami, memperhatikan, dan melakukan nilai - nilai etika yang inti. (Lickona 2013). Kelompok bermain adalah salah satu bentuk layanan PAUD pada jalur pendidikan noformal yang menyelenggarakan program kesejahteraan bagi anak sejak lahir sampai dengan enam tahun ( dengan prioritas anak usia dua tahun sampai empat tahun ) dan merupakan salah satu bentuk PAUD pada jalur nonformal yang mengutamakan kegiatan bermain sambil belajar (Asmawati, 2015). Selain landasan yuridis yang sudah tercantum diatas, pendidikan dapat diartikan secara sederhana adalah usaha manusia untuk membina kepribadiannya sesuai dengan nilainilai didalam masyarakat dan kebudayaan. Dalam perkembangannya, istilah pendidikan 
atau paedagogie berarti bimbingan atau pertolongan yang diberikan dengan sengaja oleh orang dewasa kepada anak-anak agar ia menjadi dewasa.

Menurut Philips dalam Mu'in (2011:160) Karakter adalah kumpulan tata nilai yang menuju pada suatu sistem yang melandasi pemikiran, sikap, dan perilaku yang ditampilkan, jadi karakter mempunyai ciri-ciri antara lain sebagai beriku: 1) adalah siapa dan apakah kamu pada saat orang lain sedang melihat kamu, 2) karakter merupakan hasil niai-nilai dan keyakinan-keyakinan, 3) karakter adalah sebuah kebiasaan yang menjadi sifat alamiah kedua, 4) karakter bukanlah reputasi atau yang dipikirkan oleh orang lain terhadapmu, 5) karakter bukanlah seberapa baik daripada orang lain, 6) karakter tidak relatif. Didalam karakter terdapat nilai-nilai yang tertanam terdapat 18 butir nilai yaitu: 1) Religius, 2) Jujur, 3) Toleransi, 4) Disiplin, 5) Kerja keras, 6) Kreatif, 7) Mandiri, 8) Demokratis, 9) Rasa ingin tahu, 10) Semangat Kebangsaan, 11) Cinta tanah air, 12) Menghargai prestasi, 13) Bersahabat komunikatif, 14) Cinta damai, 15) Gemar membaca, 16) Peduli lingkungan, 17) Peduli sosial, 18) Tanggung jawab. Dasar pendidikan agar peserta didik mempunyai karakter-karakter religius yang sudah dijelaskan di atas lebih diperhatikan pada akhlak yang belum termotivasi, untuk itu perlu penjelasan bagaimana sikap religius yang harus dimiliki oleh setiap peserta didik dan masyarakat sekolah dalam meningkatkan moral. Dengan nilai-nilai keyakinan membentuk karakter terutama moral sangat perlu anak usia dini dibentuk sikap dan akhlaknya agar tercermin kereligiusannya melalui gerakan sholat, perilaku sopan santun bicara, adab dalam kegiatan makan, dan berinfaq rutin setiap hari Jum'at dan tidak diajarkan dengan tradisional membaca serta menulis tetapi pola pembelajaran yang menyenangkan dengan mempraktekkan langsung sholat dhuha setiap pagi disekolah dan melaksanakan kegiatan perilaku sopan santun berbicara dengan tidak berteriak, kegiatan makan ketika anak usia dini menerapkan tata cara makan dan berdoa sebelum makan, berinfaq dengan senang hati tanpa perintah dari guru.

Karakter religius didapat dari pembelajaran yang ditanamkan berupa pembiasaan dilakukan secara rutinitas sebagai dasar pendidikan untuk mencapai tujuan akhlak yang baik, karena sesuai yang diajarkan dalam lembaga di TK Aisyiyah Bustanul Athfal 5 Sidoarjo masih ada anak tidak tertib melakukan sholat dhuha dan tidak lancar hafalan 
sholat, ada anak yang suka berteriak dan marah ketika bermain dengan teman temannya, serta infaq pada setiap Ju'mat tidak dilakukan dengan rutin serta masih perlu motivasi dari guru tentang keutamaan infaq. Dengan adanya realita tersebut perilaku anak usia dini sangat perlu di tekankan dasar literasi moral dengan suatu budaya yang menjadi kebiasaan secara tertib atau disiplin sehingga menjadikan karakter yang benar-benar tercermin akhlak religius dengan kualitas SDM pendidik dengan penerapan pembelajaran yang menarik, kreatif dan inovatif menciptakan pembelajaran dengan sholat dhuha setiap pagi menjadikan anak laki - laki sebagai imam secara bergiliran, melatih cara berbicara dengan membedakan sikap teriak maupun tidak dengan demikian dapat membedakan perilaku baik dan buruk,membuat celengan untuk tempat infaq masing-masing anak. Berdasarkan realita yang ada, untuk itu tujuan dari penelitian ini adalah untuk mengetahui bagaimana literasi moral dapat meningkatkan karakter religius pada anak usia dini serta kendala apa saja yang menghambat penerapan literasi moral dalam meningkatkan karakter religius pada anak usia dini.

\section{METODE PENELITIAN}

Penelitian ini merupakan jenis penelitian kualitatif dengan menggunakan metode wawancara yang dilakukan pada guru dan kepala sekolah di TK Aisyiyah 5 Sidoarjo dan observasi non sistematis untuk memperoleh data, diperoleh dari perilaku anak usia dini dalam pembelajaran melalui penilaian ketika anak melakukan gerakan sholat dhuha, ketika anak berinteraksi dengan teman-temannya dan ketika anak membuat celengan untuk berinfaq setiap Jum'at. Observasi dilakukan peneliti tanpa ada batasanbatasan intrumen ataupun kisi-kisi dalam fokus penelitian yang telah dilakukan, sehingga dengan demikian peneliti dapat menambah subyektifitas penelitian berdasarkan fakta dan membuat laporan - laporan ataupun catatan-catatan hasil pengamatan secara cepat dan terlibat (Wachidah, Suwignyo, and Widiati, 2017). Populasi anak usia dini di Tk Aisyiyah 5 Sidoarjo menjadikan penelitian yang dilakukan untuk menemukan ukuran penilaian literasi moral anak usia dini dengan meningkatkan karakter religius anak usia dini melalui teknik analisis.

Teknik analisis data menggunakan metode analisa deskriptif yaitu peneliti mengumpulkan data, editing, menyajikan data, dan penarikan kesimpulan perilaku anak 
usia dini di TK Aisyiyah 5 Sidoarjo ketika anak sudah bisa dan dapat menghafal bacaan sholat dhuha secara lancar, data perilaku anak yang mulai bisa membedakan perlaku baik dan buruk, serta perilaku rajin berinfaq setiap jum'at engan kreatifitas celengan yang dibuat anak, hasil implementasi tentang peran literasi moral dalam meningkatkan karakter religius di TK Aisyiyah Bustanul Athfal 5 Sidoarjo dengan subyek penelitian guru, kepala TK, wali murid dan peserta didik sejumlah 17 melalui tahap reduksi, tahapan ini dilakukan dengan pengambilan data secara langsung dengan sumber terkait dan dilakukan secara ringkas. Pengkodean yaitu penggunaan kata-kata atau kalimat dari hasil di lapangan di simbolkan atau dibentuk berupa kode-kode secara obyektif dan reflektif. Penyajian data yaitu mengumpulkan data berbentuk verbal, perilaku atau sikap dari sumber penelitian.Penarikan kesimpulan dari hasil bentuk observasi, wawancara berupa berbagai bentuk penelitian secara verbal, tingkah laku yang sudah dikodekan. Verifikasi data penelitian menggunakan teknik triangulasi metode dan tehnik presistent observasition.

\section{HASIL PENELITIAN DAN PEMBAHASAN}

\section{Peran literasi Moral Meningkatkan Karakter Religius anak Usia Dini di TK Aisyiyah Bustanul Athfal 5 Sidoarjo.}

Pendidikan anak usia dini merupakan pembelajaran sebagai dasar pembentukan karakter moral secara religius sejak dini yang membawa dampak cerminan tingkah laku atau akhlak hingga anak menjadi dewasa. Menurut penelitian tentang pentingnya sholat dan sedekah dalam agama Islam, manusia mengemban sebagai pemimpin dan makhluk sosial yang selalu membutuhkan batasan-batasan sebagai bekal sampai usia dewasa (Afrida, 2018). .Perintah agama dalam menjalankan sholat dan sedekah selalu beringan sehingga perlu penekanan pembelajaran pada anak usia dini untuk mengembangankan karakter religius di setiap lingkungan, baik lingkungan keluarga, sekolah dan masyarakat. Perkembangan anak menjadi dewasa banyak dipengaruhi faktor-faktor pendukung baik secara positif maupun negatif, jika seorang anak telah tertanam sikap moral yang baik dengan tingkah laku maupun pembiasaan akan bisa menjaga perkembangan akhlak secara stabil dimanapun anak berada, sehingga sebagai wacana anak dalam pembelajaran PAUD perlu adanya motivasi dan bukti kongkrit dalam 
pentuk keteladanan gerakan literasi moral. Pembelajaran penuh dengan kreativitas mengembangkan bakat anak menuntut senang untuk bermain dan berinteraksi untuk mengembangkan pengetahuan dalam penelitian catron \& Allen,1999 (Priyanto, 2015).

Anak usia dini lebih mudah memahami jika langsung mengenal dunia kongkrit menurut Samani dan Hariyanto (2011:44) bahwa karakter merupakan rancangan yang dilakukan secara matang dan dilakukan dengan tujuan serta evaluasi yang dicapai untuk memperoleh nilai-nilai etis (Selatan, 2019). Peran literasi moral dilakukan dalam pembelajaran di TK Aisyiyah Bustanul Athfal 5 Sidoarjo berupa sholat dhuha yang dilakukan masih belum dapat terlihat hafalan secara lancar dan sholat secara tertib, dan juga Jum'at sedekah atau berinfaq masih belum dilaksanakan secara rutin hal ini terlihat dari perolehan uang infaq yang masih kurang rata - rata, jika setiap anak dalam setiap Jum'at bersedekah secara rutin, maka dapat dipastikan perolehan minimal dalam satu minggu mendapatkan sejumlah 17 anak. Sehingga bisa dilihat peran literasi moral dalam meningkatkan karakter religius anak masih kurang.Beberapa faktor yang mempengaruhi terwujudnya peran literasi moral dalam meningkatkan karakter religius pada anak usia dini dapat dibuktikan dengan dukungan data sebagai berikut:

Tabel 1.1

Data jumlah peserta didik sebelum diadakan penelitian peran literasi moral meningkatkan karakter religius pada anak usia dini

\begin{tabular}{|c|c|c|c|c|}
\hline No. & $\begin{array}{c}\text { Bulan/ } \\
\text { Minggu }\end{array}$ & $\begin{array}{c}\text { Jumlah } \\
\text { peserta didik }\end{array}$ & $\begin{array}{c}\text { Jumlah Peserta didik } \\
\text { yang tidak karakter } \\
\text { religius dalam sholat } \\
\text { dhuha }\end{array}$ & $\begin{array}{c}\text { Jumlah Peserta } \\
\text { didik yang tidak } \\
\text { karakter religius } \\
\text { dalam Jum'at } \\
\text { sedekah }\end{array}$ \\
\hline 1 & I & 17 & 5 & 4 \\
\hline 2 & II & 17 & 9 & 6 \\
\hline 3 & III & 17 & 8 & 7 \\
\hline 4 & IV & 17 & 12 & 11 \\
\hline
\end{tabular}

Berdasarkan hasil observasi dan wawancara sebelum diberikan tindakan peran literasi moral dalam meningkatkan karakteristik religius anak usia dini diperoleh hasil indikator capaian dengan kriteria BSH (Berkembang Sesuai Harapan) Prosentase masih pada tingkat $57 \%$ tidak sholat dengan tertib dan lancar, sudah sholat tertib dan lancar $43 \%$, tidak sedekah 57\%, sudah sedekah $43 \%$ dari prosentasi tersebut dapat dilihat 
peran literasi moral melalui karakter religius peserta didik dengan sholat tertib lancar dan Jum'at sedekah belum sesuai target . Karena penelitian mengatakan pada anak usia dini perlunya stimulasi dan penghargaan untuk mengembangkan rasa positif dan memotivasi untuk melakukan kegiatan dan memaksimalkan usia kecemasan yang mudah diasah dan ditanamkan nilai - nilai moral (Rahman 2009). Dalam hal ini, peran literasi moral dalam peningkatan karakter dalam pembelajaran belum bisa ditanamkan guru, sehingga perlu diadakan tindakan.

Berdasarkan hasil observasi dan wawancara sesudah diberikan tindakan peran literasi moral dalam meningkatkan karakteristik religius anak usia dini diperoleh hasil indikator capaian dengan kriteria BSH (berkembang Sesuai Harapan) Prosentase masih pada tingkat $34 \%$ tidak sholat dengan tertib dan lancar, sudah sholat tertib dan lancar $66 \%$, tidak sedekah 34\%, sudah sedekah 66\% Dengan hasil tersebut terlihat bahwa peran literasi moral dalam meningkatkan karakter religius pada anak usia dini sudah mulai meningkat dari rata - rata prosentase indikator pencapaian sesuai dengan RPPH , diadakan rutinitas sholat dhuha dan jum'at sedekah disertai dengan membentuk celengan dari botol bekas dari pengamatan yang dilakukan sebagai sarana peserta didik untuk pembelajaran yang menyenangkan di PAUD Aisyiyah 5 Sidoarjo (Wachidah, Suwignyo, and Widiati, 2017). Pada peran literasi moral sudah dilaksanakan peserta didik secara berkelanjutan membentuk pembiasaan karakter religius dalam setiap kesempatan dan tempat terutama dilingkungan sekolah dengan $66 \%$ berkembang sesuai harapan (Khamalah, 2017).

Dari hasil penelitian sebelum dan sesudah diberi tindakan tersebut dapat dilihat peningkatan dari angka $34 \%$ menjadi $66 \%$ pada kriteria pengembangaan karakter sudah sholat dengan tertib dan lancar, sedangkan pada jum'at sedekah dari $34 \%$ menjadi $66 \%$ yang mencerminkan perilaku atau akhlak, budi pekerti, karakter religius juga signifikan karena sesuai target jumlah nominal yang diharapkan prosentase yang meningkat sesuai dengan indikator penilaian serta menunjukkan keberhasilan 


\section{Diagram 1 \\ Capaian pengembangan Peran literasi Moral dalam Meningkatkan Karakter Religius Anak Usia Dini}

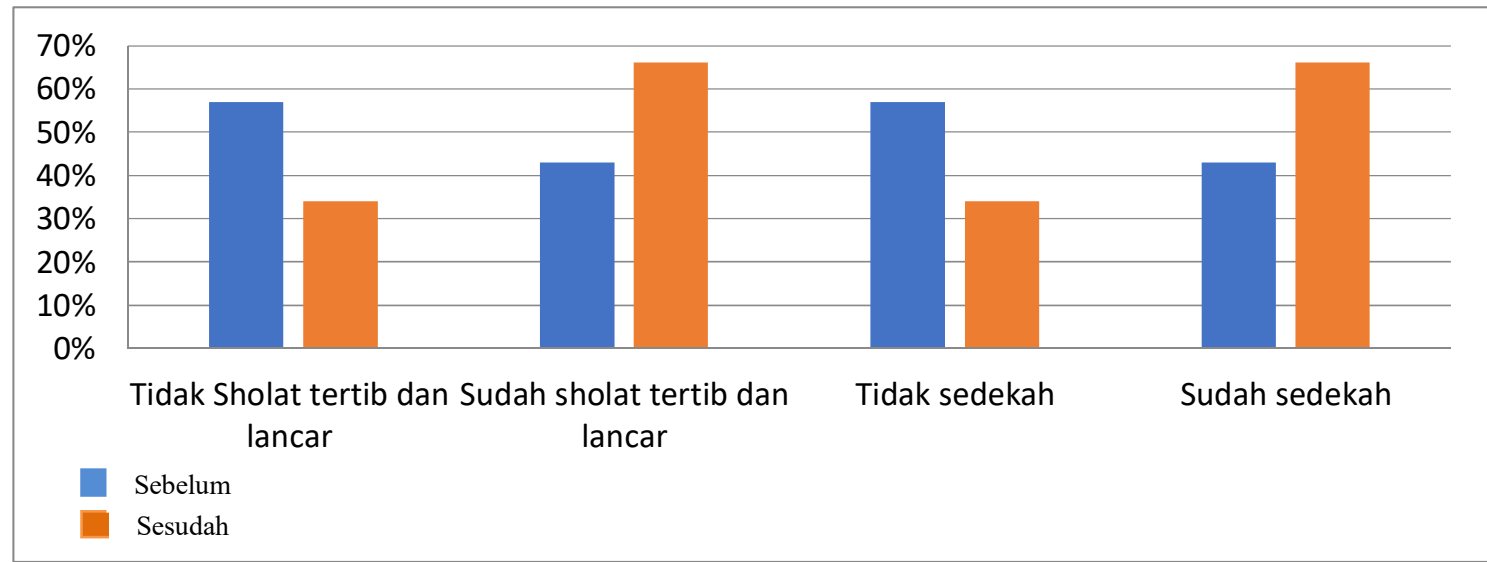

Dari gambaran diatas dapat diperoleh bahwa peserta didik melaksanakan peran literasi moral dalam meningkatkan karakter religius anak usia dini secara signifikan dalam perkembangan pembelajaran didukung dengan hasil laporan wawancara di PAUD Aisyiyah 5 Sidoarjo sebagai berikut:

Tabel 1.2

Hasil Wawancara Kepala Sekolah, Guru,Orang Tua, Peserta Didik

\begin{tabular}{|l|l|}
\hline Obyek Wawancara & \multicolumn{1}{|c|}{ Hasil } \\
\hline Kepala Paud & $\begin{array}{l}\text { "Kegiatan peran literasi moral berupa kegiatan yang } \\
\text { diadakan sholat dhuhadan sedekah setiap Jum'at ini } \\
\text { merupakan tujuan dari salah satu visi dari PAUD Aisyiyah 5 } \\
\text { Sidoarjo, untuk mengembangkan perilaku peserta didik yang } \\
\text { positif". }\end{array}$ \\
\hline Guru & $\begin{array}{l}\text { "Peserta didik dengan motivasi pengetahuan peran literasi } \\
\text { moral dalam meningkatkan karakter religius lebih giat lagi } \\
\text { sholat dhuha dan Jum'at sedekah dan menjadi pembiasaan } \\
\text { pada setiap kesempatan". }\end{array}$ \\
\hline Orang Tua & $\begin{array}{l}\text { "Pembelajaran ini sangat dibutuhkan peserta didik sebagai } \\
\text { penguatan keimanan umat muslim, dan pembiasaan yang } \\
\text { positif untuk anak usia dini }\end{array}$ \\
\hline Peserta didik & $\begin{array}{l}\text { "Bu aku besok Jum'at mau jumat sedekah dan aku sudah } \\
\text { sholat bersama ayah. }\end{array}$ \\
\hline
\end{tabular}

Keterangan:

\section{Laporan wawancara Kepala PAUD, Guru, Orang Tua, Peserta didik}

1. Wawancara Kepala Paud bangga dan senang terhadap peran literasi moral dalam meningkatkan karakter religius anak usia dini

2. Wawancara guru yang terdiri dari 6 orang, $66 \%$ dari peserta didik menunjukkan perubahan sikap karena kegiatan Jum'at sedekah menyenangkan. 
3. Wawancara untuk orang tua mengambil sample 7 wali murid, berkomentar rata - rata senang peran literasi moral dilaksanakan di sekolah dan didukung orang tua.

4. Wawancara kepada peserta didik Anak senang melaksanakan peran literasi moral dalam pembiasaan dan kegiatan pembelajaran.sesuai penelitian yang dilakukan oleh (Diana 2010).

\section{Hambatan Peran literasi Moral dalam Meningkatkan Karakter Religius Anak Usia Dini}

Kurangnya perhatian orang tua secara intens di rumah, karena kesibukan berkarier, menyebabkan anak tidak rutinitas melanjutkan hafalan maupun bacaan sholat secara lancar sehingga penanaman peran literasi moral tidak sesuai pembelajaran yang diberikan disekolah (Khaironi 2017). Pengaruh perkembangan tehnologi berupa gadget menurukan kualitas moral dan karakter religius anak usia dini karena pada tingkatan tersebut masih belum mengetahui pemahaman secara maya. Kurangnya rasa empatit anak usia dini karena tidak terbiasa bersedekah atau berbagi sehingga uang yang diberikan orang tuanya tidak dimasukkan kedalam gelas sedekah masing - masing anak (Siswanta 2017).

\section{SIMPULAN DAN SARAN}

Perilaku anak usia dini di TK Aisyiyah 5 Sidoarjo telah melalui perubahan dan perkembangan perilaku gerakan sholat dhuha dengan lancar bacaan sholat serta dapat mulai aktif berinfaq tanpa motivasi dari guru, sehingga literasi moral merupakan pengetahuan baik secara verbal maupun non - verbal dalam mengembangkan akhlak untuk membentuk karakter religius pada anak sejak usia dini sudah dapat ditingkatkan dengan hasil dari data penelitian berupa data wawancara dan observasi yang dilakukan. Peran pendidik mencapai peran literasi moral dalam peningkatan karakter religius anak usia dini menentukan pencapaian program karena perlunya inovasi dalam pembelajaran yang menyenangkan, sesuai pernyataan dalam penelitian guru merupakan kunci efektifitas serta efisien dalam meningkatkan kemampuan dasar rajin membaca dan menulis (Widodo, 2015). Penelitian ini bisa direkomendasikan pada suatu jenjang pendidikan yang sama dengan anak usia dini di lain tempat. Bagi peneliti selanjutnya hendaknya dilakukan dengan penelitian yang lebih luas. 


\section{DAFTAR PUSTAKA}

Afrida, Afrida. 2018. "Hakikat Manusia dalam Perspektif Al-Qur`an." Al-Qisthu: Jurnal Kajian Ilmu-ilmu Hukum 16(2): 54.

Asmawati, Luluk. 2015. Pengelolaan Kegiatan Pengembangan Anak Usia Dini.

Diana, Mutiah. 2010. بيماريهاى داخلى Psikologi Bermain Anak Usia Dini.

Khaironi, Mulianah. 2017. "Pendidikan Karakter Anak Usia Dini." Jurnal Golden Age Universitas Hamzanwadi.

Khamalah, Nur. 2017. "Penguatan Pendidikan Karakter di Madrasah." Jurnal Kependidikan 5(2): 200-215.

Lickona, Thomas. 2013. No Educating For Character Mendidik Untuk Membentuk Karakter, Bagaimana Sekolah Dapatkan Tentang Sikap Hormat Dan Bertanggung Jawab.

Nurdiyanti, Eko dan Edy Suryanto. 2010. "Pembelajaran Literasi Mata Pelajaran Bahasa Indonesia Pada Sisiwa Kelas V Sekolah Dasar.” Jurnal Paedagogia. 13(2): 116.

Pancarrani, Berlian, Isma Wakhidatul Amroh, and Yunita Noorfitriana. 2017. "Peran Literasi Orang Tua Dalam Perkembangan Anak." BIBLIOTIKA : Jurnal Kajian Perpustakaan dan Informas: 21-27.

Priyanto, Aris. 2015"Pengembangan Kreativitas Pada Anak Usia Dini Melalui Aktivitas Bermain." Jurnal Ilmiah Guru Caraka Olah Pikir Edukatif 0(2).

Rahman, Ulfiani. 2009. "Karakteristik Perkembangan Anak Usia Dini." Lentera Pendidikan: Jurnal Ilmu Tarbiyah dan Keguruan.

Selatan, Denpasar. 2019. "Dengan Pendekatan Holistik Putu Aditya Antara The Implementation Of Early Childhood Character Education." 14(1): 17-26.

Siswanta, Jaka. 2017. "Pengembangan Karakter Kepribadian Anak Usia Dini (Studi Pada PAUD Islam Terpadu Di Kabupaten Magelang Tahun 2015).” INFERENSI 11(1): 97.

Wachidah, L.R, H Suwignyo, and N Widiati. 2017. "Potensi Karakter Tokoh Dalam Cerita Rakyat Sebagai Bahan Bacaan Literasi Moral." Jurnal Pendidikan: Teori, Penelitian, dan Pengembangan 2(7): 894-901.

Widodo, Slamet dkk. 2015. "Membangun Kelas Literat Berbasis Pendidikan Lingkungan Hidup Untuk Melatihkan Kemampuan Literasi Siswa Di Sekolah Dasar." Prosiding Seminar Nasional Pendidikan. 